\title{
Comfortable Pedestrian Ways With a Climate Sensitive Urban Design Approach in The Old City Semarang
}

\author{
Rina Kurniati*, Wakhidah Kurniawati, Diah Intan Kusumo Dewi, Annisa Sarasadi, \\ Endah Kartika Syahri \\ Department of Urban and Regional Planning, Faculty of Engineering, Diponegoro University
}

\begin{abstract}
The city of Semarang is one of the cities in Indonesia that experiences the phenomenon of heat stroke due to climate change. These conditions cause an increase in the average surface temperature of the city to $22-40^{\circ} \mathrm{C}$ which is included in the category of discomfort for outdoor activities. This is certainly very disturbing for various forms of outdoor activities, such as pedestrian activity. The Old City of Semarang is included in the public area which in the last 5 years seeks to improve the arrangement of the area through the development of pedestrian ways. However, the development that has been carried out is considered not able to create a comfortable climate for pedestrians due to high regional temperatures, especially during the day. For this reason, this study aims to examine how to create a comfortable pedestrian ways to climate change, especially in the Old City Region of Semarang. The method used in the form of analysis of the level of thermal comfort using the ArcGIS application and pedestrian ways analysis using vegetation distribution and building shadow analysis. The result will be found elements of city design that can create pedestrian comfort in the Old City Region of Semarang.
\end{abstract}

Keywords. Pedestrian Ways, Old Town, Climate, City Design, Comfort.

\section{Introduction}

Changes in the world climate in the last few decades showed a significant increase. Indonesia is one of the countries most affected by climate change, which causes an average increase in surface temperature every year to $0.3^{\circ} \mathrm{C}$ [1]. Population growth and its influence on land-use change are one of the triggers for the increased surface temperature of the earth. According to WRI in [1], Indonesia became one of the

\footnotetext{
*Corresponding author: rina.kurniati@pwk.undip.ac.id
} 
countries ranked 4 th as the country with the most population in the world. Land-use change and illegal logging cause up to $85 \%$ loss of green land.

This condition is most severe in most urban areas which are dominated by developed land with high population density. So that the phenomenon that occurs at this time is an increase in city temperatures that are very extreme or often referred to as the Urban Heat Island (UHI) phenomenon. According to research conducted by Pamungkas [2], cities in Indonesia such as Semarang City continue to experience the growth of built-up land. The increase built of land built in the city of Semarang in the past 10 years reached $13 \%$ with the most land-use change in the agricultural area. These conditions triggered increasingly hot surface temperatures in the city of Semarang to $22-40^{\circ} \mathrm{C}$ in 2018 which is 2008 the average surface temperature was only $18-33^{\circ} \mathrm{C}$.

Based on this phenomenon, outdoor activities at this time remain something that is quite important and very influential on the sustainability of urban life. In the debate about the importance of a city in creating a comfortable and safe city life for its people, the surface temperature of the city is one indicator that plays an important role in forming a livable city. So at this time, it is necessary to adjust the design elements of the city design that can adjust to the temperature conditions of the city which is getting hotter [3]. The construction of pedestrian ways in public areas such as the Old Semarang City Region has become one of the platforms that support community outdoor activities, especially in its purpose for recreation. According to Carr [4], the pedestrian ways is one of the public spaces that serve to connect between places and is very closely related to the surrounding space and building system. In addition, this pedestrian lane serves to provide comfort for pedestrian movements which are usually parallel to the vehicle traffic lane [5].

The pedestrian ways in old town is one of the development products in the city of Semarang that is being intensified by the government at this time. As an increasingly developed heritage tourism area, triggering the development of commercial buildings that shift the existence of green lands. The construction of pedestrian ways and roadworks has made the face of the Old City more organized so that it has brought quite a number of tours, especially from outside the region. However, the question now is whether the design of the pedestrian ways is comfortable for visitors. Given the challenges facing the city of Semarang today is an increase in surface temperatures that are quite extreme which will certainly interfere with outdoor activities such as pedestrian activity. For this reason, we need an adjustment to the design of pedestrian ways design that can adjust to the climate conditions of the city so as to create a comfortable pedestrian facility for its users.

\section{Research Method}

The method used in this research is quantitative research methods. Where in the process of data processing and analysis using numerical calculations. The analysis used in this study is a method of thermal comfort analysis and pedestrian ways design analysis. Thermal comfort analysis is used to show how the surface temperature picture of the Semarang Old Town Area. The thermal comfort analysis process uses the Lansat Image 10 data processing using the ArcGIS 10.3 application. Thermal comfort analysis by looking at the Land Surface Temperature (LST) is done by converting the Landsat 8 Band 10 Image to the Land Surface Temperature. 
Then the pedestrian ways design analysis is used by using vegetation analysis and also the shadow director of the building (setting). Where this analysis is used to determine the level of sunlight resistance to the pedestrian ways in the Old City Area. Determination of vegetation points using spatial data processing from field observations by showing the location of vegetation and the amount of vegetation in the existing area. In the analysis of the shadow of buildings around the pedestrian ways seen from the time of the maximum surface lighting sources at 09:30 WIB and 17:30 WIB. Then make use of building height data for data processing in Sketchup. The resulting object image adjusts to the coordinates of the area that was previously processed using the ArcGIS mapping application before it is then processed in the Sketchup application. The advantage of this method is that in addition to being in accordance with existing conditions, the process is also easy.

\section{Theories}

\subsection{Climate Sensitive Urban Design}

Climate Sensitive Urban Design is a responsive planning or design concept with basic elements of climate including solar lighting, wind speed, and temperature $[6,7,8]$. According to Emanuel (2005), the concept of Sensitive Urban Design is a concept that is responsive to climate and is an approach that refers to the issue of sustainable development [1]. Basically, this concept aims to obtain the conditions of thermal equality for regional space users so as to improve the quality of life of the people $[7,8,9]$. Therefore Sensitive Urban Design is one of the components that must be considered in the Building and Environmental Planning. Thermal comfort has a benchmark based on climate elements influencing the micro-conditions of the region $[10,11]$, among them the first air temperature in a tropical climate has a comfort interval of $16-30^{\circ} \mathrm{C}$, secondly the humidity at a comfort interval between $20 \%-90 \%$, third exposure to sunlight depends on the geographical conditions of the region so it needs to intervene in the structure of the building, the four wind speeds that create thermal comfort in the tropics with a magnitude $>2.0 \mathrm{~m} / \mathrm{s}$ during the day.

The calculation of the thermal comfort scale that can be felt by regional space users is based on the numerical value of the Predict Mean Vote (PMV) established by The American Society of Heating, Refrigerating, and Air-Conditioning Engineers (ASHRAE) and applies in tropical countries. Numerical values of PMV Hot 3, Warm 2, Slighty Warm 1, Neutral 0, Slighty Cool -1, Cool -2, Cold -3 [11]. In order to improve Thermal comfort, this is done by including consideration of vegetation, material, water bodies, shading, and the formation of wind corridors in urban areas. The function of vegetation in urban areas is to imagine and reduce race. In addition, there is a need for limitation and control of Building Base Coefficient and control of Building Floor Coefficients in the urban center area.

\subsection{Pedestrian Ways}

Pedestrian ways are one of the elements in urban design. In addition, pedestrian ways are part of the city that is formed alone or planned along the side of the road that connects places and has a connection with the system of space and buildings [12]. According to the Ministry of Public Works No. 3 of 2014, the pedestrian ways can be developed into a ways with mixed functions [13]. Besides pedestrian ways are divided into various types including Enclosed Mall, Transit Way, Semi Mall, Full Mall. The 
distribution of pedestrian lane zones by the NZ Transport Agency (2009) includes pedestrian zones, road furniture zones, route or road width, frontage zones [14].

\subsection{Old Town Semarang as Case Study}

The Old City area is one of the crocodile reserve areas in the city of Semarang which has an area of 33 hectares and is included in the Tanjung Emas Kelurahan, North Semarang District, and Purwodinatan Kelurahan, Central Semarang District. The description of the existing conditions and territorial boundaries in the Old City area is as illustrated in Fig 1.

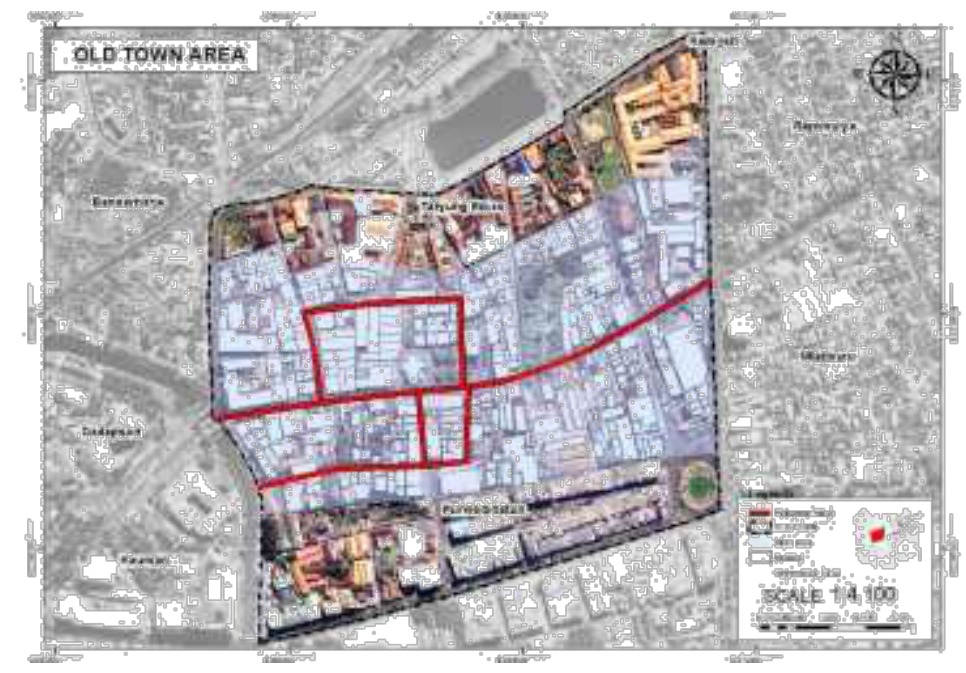

Fig. 1. Semarang Old Town Area

- North : Tawang Street

- South : KH Agus Salim Street

- West : Cendrawasih Street

- East : Semarang River, Sendowo Street and Empu Tantular Street

This area has around fifty ancient buildings that still stand firm and have a history of colonialism in Semarang. Based on data made in 1935 [15], at that time the Old Town Region had built buildings such as a train station, tram station, Catholic Church, Christian Church, Sister, notary office, editorial office, consulate (Muangthai, Belgium, France, United Kingdom), banks, plantation companies, nursing homes, clubs, publishing houses, orphanages, district courts, government offices, trade offices, technical schools, staadschouwburg, hotels, and police stations. As for this study based on Fig 1, the pedestrian ways in the Old City area is divided into 7 parts, namely Garuda Street, Branjangan Street, Srigunting Street,

Letjen Soeprapto Street, Gelatik Street, Suari Street, and Kepodang Street. The micro analysis area used in this study covers an area that reaches 50 meters from the pedestrian lane or a radius of 50 meters from the road network. This area is the main location of historical tourism activities dominated by land use for historic and commercial buildings. 


\section{Result and Discussion}

\subsection{Land Surface Temperature}

The level of thermal comfort in an area is one important component in urban design. The Old City area of Semarang is a historical tourist spot that needs to be considered for its comfort level, one of which is the accessibility convenience. Through the calculation of the Land Surface Temperature will be obtained the value of surface temperature in an area, where that value can be used as a recommendation for the design of pedestrian ways to improve the comfort of the community and tourists.

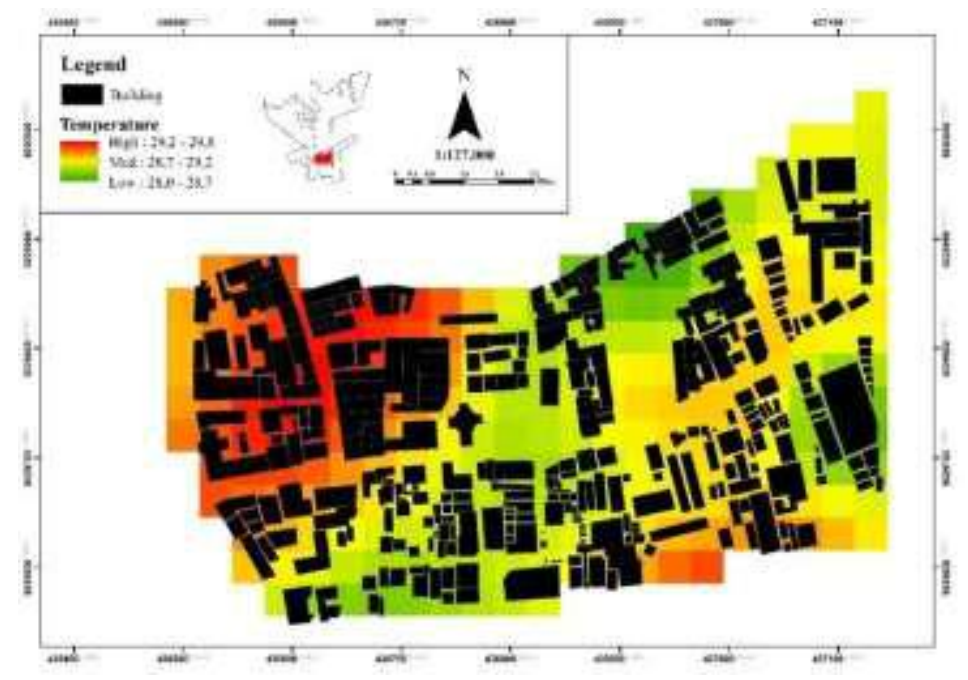

Fig. 2. Land Surface Temperature

Based on the calculation of the Land Surface Temperature (LST) in the Old Town Region, the temperature value is $27^{\circ} \mathrm{C}-29^{\circ} \mathrm{C}$ on June 16,2020 , which is classified as normal in tropical regions (Fig 2). The highest temperature is located in the northwestern part of the delineation area, which includes parts of Letjen Soeprapto Street, Garuda Street, and Branjangan Street. Based on the temperature value obtained, the design of the design can be adjusted to the condition of the building, vegetation, the direction of sunlight on the pedestrian ways.

\subsection{Pedestrian Ways Comfort Analysis}

The Old City area is one of the historical attractions that currently has a more ordered appearance of the area due to road and pedestrian improvements. A comfortable pedestrian ways is one that can accommodate pedestrians by providing facilities, without any interruption in walking. Based on Fig 3. shows that the characteristics of the arrangement of pedestrian ways in each section have some differences. The pedestrian ways on Letjen Soeprapto Street has the largest area, this is because in this area it is the main entrance that connects old town with the surrounding area.

The size of the road is 5 meters wide and the pedestrian ways is 2 meters wide, complete with street lights, benches, road dividers, and small trees. The characteristics of structuring pedestrian ways on Kepodang and Branjangan Roads are almost the same as those on Letjen Soeprapto Street, but in this area, the width of the road and 
the pedestrian ways have a narrower size. Pedestrian ways on others are only equipped with small trees and street lights, or there are no facilities at all like on Gelatik Street. That is because the Gelatik Road area is part of the function of residential areas which have relatively small road sizes.

According to research conducted by Aida [16], there are 3 main pedestrian activities in the Semarang Old Town area. Important activities consisting of activities moving to the workplace, which is driven by the many locations of office buildings in the Old City and surrounding areas. Other activities are optional activities in the form of historical tourism activities which can be influenced by climate and weather conditions. Then, there is a social activity in the form of community interaction, especially in public spaces such as parks.

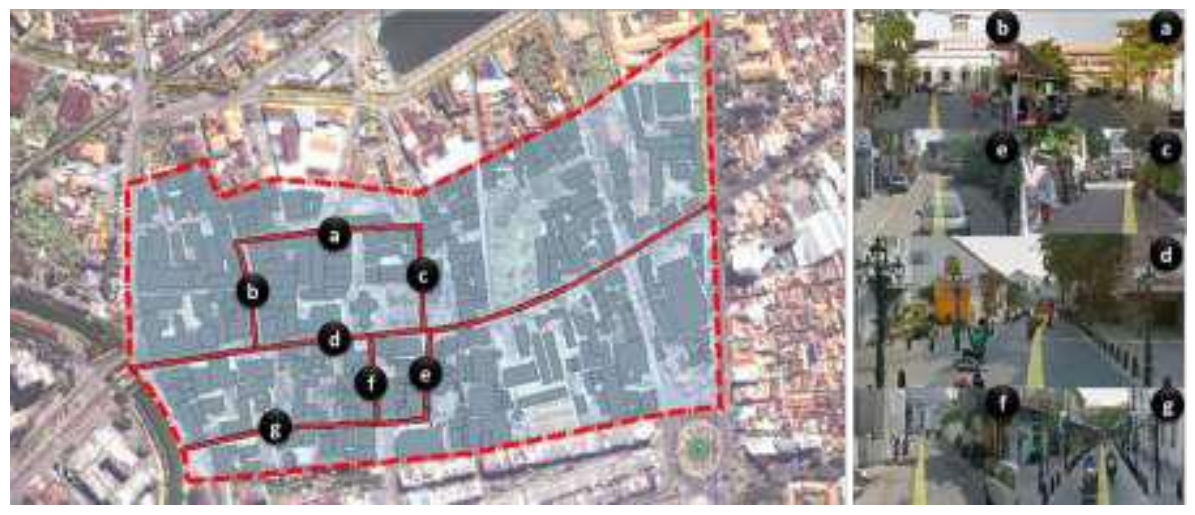

Fig 3. The existing condition of the pedestrian ways : a) Garuda Street, b) Branjangan Street,
c)Srigunting Street, d) Letjen Soeprapto Street, e) Gelatik Street, f) Suari Street, and g) Kepodang Street.

Based on the results of vegetation removal, Letjen Soeprapto Street and Kepodang Street are the pedestrian routes that have the most vegetation compared to other pedestrian routes. In general, there are two types of vegetation based on the size of their canopy consisting of small-sized vegetation and large-type vegetation. The type of small-sized vegetation located on the pedestrian ways is an angsana tree and a butterfly tree with a leaf canopy that is not too tight. While large vegetation is dominated by tamarind trees, especially in areas near Srigunting Park. Trembesi trees in this area greatly influence the formation of microclimate, so that the surrounding air becomes cooler. The shape of the area is dominated by cultural heritage buildings with concrete materials and has a large size, causing the presence of vegetation is still considered lacking in creating a comfortable climate on the pedestrian ways in the Old City Today.

All parts of the region or settings that can block direct sunlight can affect the decrease in the surface temperature of the earth [17]. Analysis of the direction of the building's shadow based on sunlight is one of the alternatives in determining pedestrian ways design that is comfortable for pedestrians to use. Buildings located along the pedestrian ways have an average height of 5-14 meters. In this case, the researcher uses the latest shadow direction analysis on June 16, 2020, which is divided into two types of buildings based on the direction facing them. Based on Fig 4, buildings that have a direction facing east or west when viewed based on maximum sunlight at 9:30 am, it appears that the resulting shadow is directed towards the back or front of the building if exposed to sunlight at 5:30 $\mathrm{pm}$. Meanwhile, buildings with a position facing north or south tend to produce a shadow 
on the left side at 09.30 and the right side at 17:30. In this case, the building's most advantageous position for pedestrians is the position of the building facing west or east, because the shadow of the building will cover the pedestrian ways at the highest peak temperature of 29 degrees Celsius at $09.30 \mathrm{am}$.

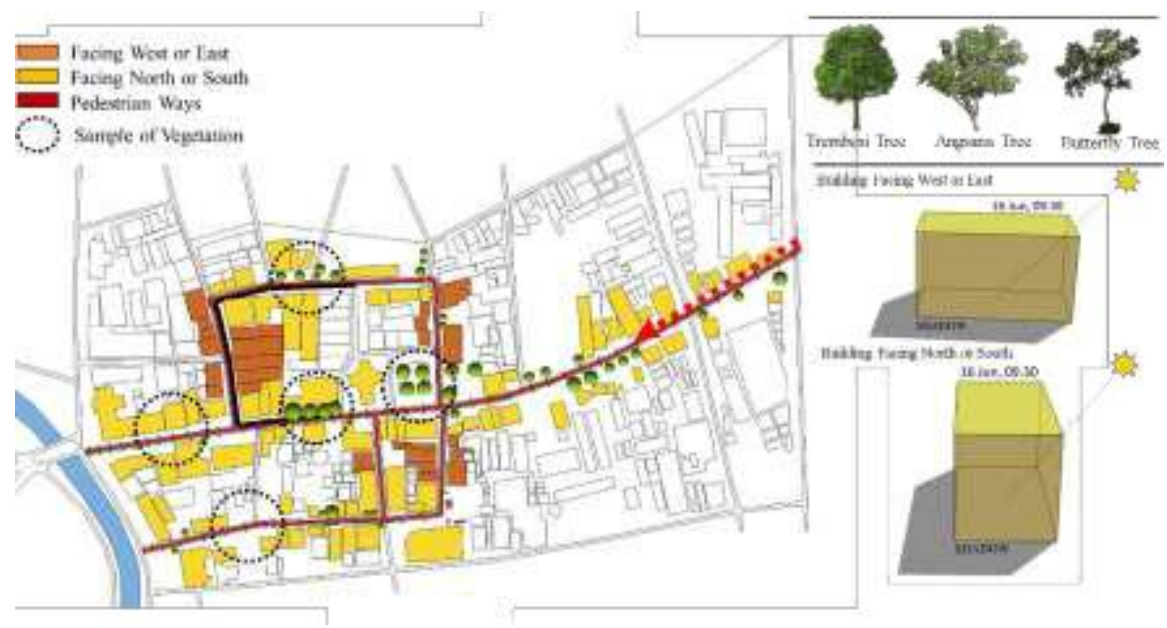

Fig 4. Vegetation and building position

More broadly, if the shadow position of the whole building along the pedestrian ways is compared based on sunlight at 09.30 and the position of the sun at 17:30, it appears that at 09:30 when the sun is very hot buildings along the pedestrian ways cannot produce shadows that reach up to the pedestrian ways. Only buildings on Suari Street produce shadows covering the side of the road. That is because on Suari Street has a relatively small road width with a fairly close distance between buildings. Meanwhile, if seen in Fig. 5, at 17:30 the entire building is able to reach all the pedestrian ways. There are only 3 locations that cannot be reached by the shadow of the building. The temperature of the area at 17:30 reached 28 degrees Celsius or relatively comfortable to use for walking activities. Thus, the current shadow position of the building adds to the ideal temperature comfort level around the pedestrian ways area.

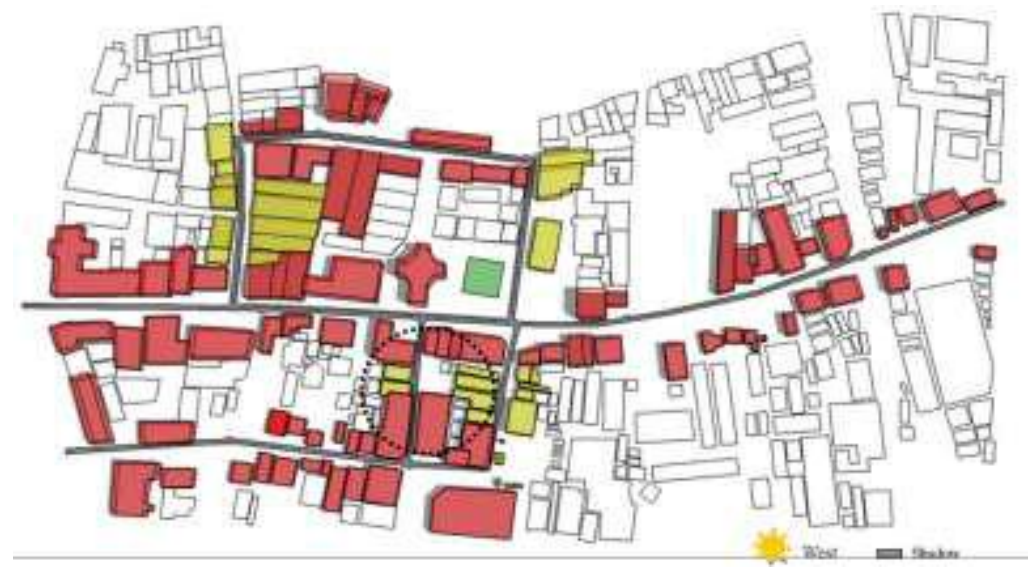

(a). 16 June 2020 , time : 09.30 WIB 


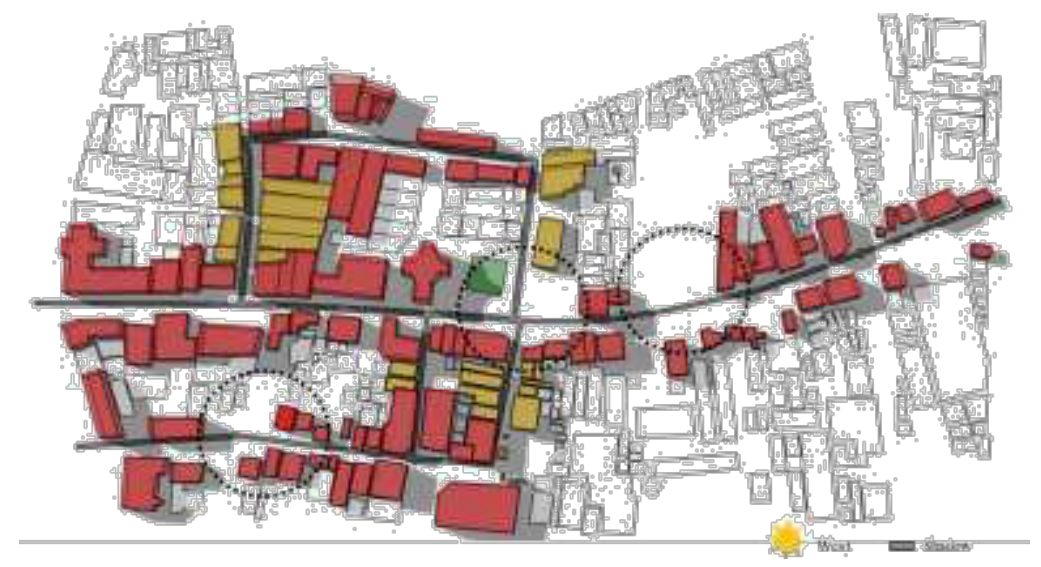

(b). 16 June 2020 , time : $17.30 \mathrm{WIB}$

Fig 5. Spread of buildings along a pedestrian ways

\subsection{Response : Design Implementation}

Based on the results of the previous analysis, a design recommendation is needed that can be added to the pedestrian ways area in the Old City area of Semarang. Where according to Esti [18], the ideal air temperature or temperature limit in tropical climate regions is in the range of $22.5^{\circ} \mathrm{C}-29.5^{\circ} \mathrm{C}$. So at this time needed a design plan for the arrangement of pedestrian ways in the Old City that can reduce air temperatures to reach a comfortable limit for pedestrians. The response to the implementation of pedestrian designs that can adapt to tropical climate conditions are as follows:

- In this area needed an increase in the amount of vegetation with a canopy by $40 \%$ with shade tree species that can reduce the air temperature level as much as $3.5^{\circ} \mathrm{C}$. The recommended tree species can be a tabebuia tree as a shade tree as well as enhancing the aesthetics of the region. The recommended distance for planting trees is 6-7 meters between trees [5].

- Then, it is necessary to add shelter or shade which is designed by applying the concept of green corridor Fig 6. With the procurement of pergola placed on the pedestrian ways. Pergola is a corridor or corridor formed by supporting pillars and equipped with hanging plants or green vines [19].

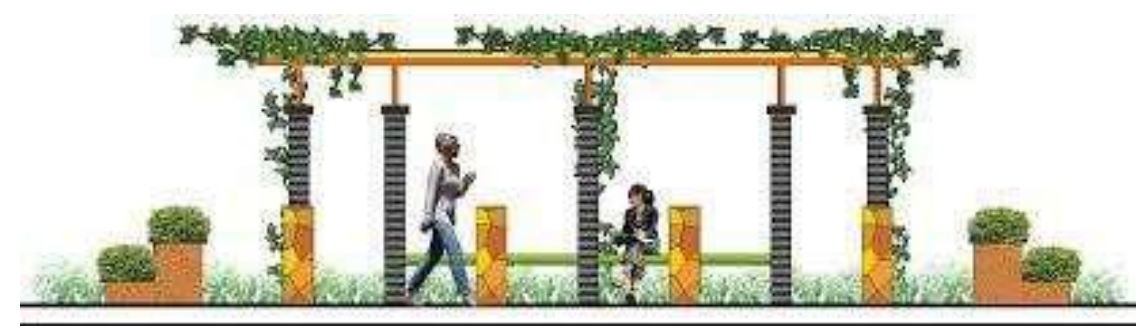

Fig 6. Pergola design (source : UNNES Journal, 2012) 


\section{Conclusion}

Planning and design of an area can not be separated from climate impacts other than population growth which has an impact on increasing land use in urban areas is increasing. This phenomenon can cause an increase in urban temperatures. But outdoor activities are now important to support urban sustainability. Thus the need for planning and design that is comfortable and safe for the community. One of them is in the Old City area of Semarang, which is one of the historical attractions that need to be considered the level of comfort and safety, especially on the pedestrian ways, the pedestrian ways that accommodates pedestrians with various facilities without disturbing pedestrians.

Based on this research the pedestrian ways in old town is divided into 7 sections Garuda Street, Branjangan Street,Srigunting Park Street, Letjen Suprapto Street, Gelatik Street, Suari Street, and Kepodang Street, which will be analyzed by analyzing the direction of the building's shadow based on June 16, 2020,to obtain a building's advantageous position for the walk is the building facing west or east, because the shadow of the building will cover the pedestrian ways at a peak temperature of $29^{\circ} \mathrm{C}$ at 09:30 am, but if the overall shadow position of the building can reach the entire pedestrian ways at 17:30. The regional temperature at 17:30 reached $28^{\circ} \mathrm{C}$. Also based on the surface temperature value of June $16,2020,27^{\circ} \mathrm{C}$ $-29^{\circ} \mathrm{C}$ so that it is still relatively comfortable for activities.

\section{Acknowledgment}

This research was funded by "Direktorat Riset dan Pengabdian Masyarakat, Deputi Bidang Penguatan Riset dan Pengembangan, Kementerian Riset dan Teknologi/Badan Riset dan Inovasi Nasional" through Penelitian Dasar Grant 2020 by Universitas Diponegoro.

\section{References}

[1] M. R. Emannuel, "An Urban Approach to Climate-Sensitive Design," New York, (2005)

[2] B. A. Pamungkas, K. Munibah, and S. Soma, "Land use changes and relation to urban heat island (case study : Semarang City, Central Java," IOP Publishing, Bogor, (2019)

[3] A. Djukic, M. Vukmirovic, S. Stankovic, "Principles of climate sensitive urban design analysis in identification of suitable urban design proposals. Case study: Central zone of Leskovac competition," Energy and Building, no. 115, pp. 2335, (2016)

[4] S. Carr, Public Space, Cambridge: Cambridge University Press, 1992.

[5] J. D. Chiara, and L. Kopelmen, Site Planning Standards, New York: McGraw Hill Inc, (1978)

[6] N. Kaya, and O. Mengi, "How Sensitive We Build to Climate ? Design for Comfortable Urban Environment," 47th ISOCARP Congress, (2011)

[7] E. Tapias, and G. Schmitt, "Climate-Sensitive Urban Growth : Outdoor Thermal Comfort as an Indicator for the Design of Urban Spaces WIT Transactions on Ecology and the Environment," (Switzerland: WIT Press), (2014) 
[8] K. D. Kusumastuty, H.W Poerbo, and M. D Koerniawan, "Climate-sensitive urban design through Envi-Met simulation," IOP Conf. Series: Earth and Environmental Science , (2018)

[9] M. D. Koerniawan, " The Simulation Study of Thermal Comfort in Urban Open Spaces of Commercial Area Using EnviMet Software AIJ Japan (Tokyo)," (2015)

[10] H. Koch-Nielsen, " Stay Cool : A Design Guide for the Built Environment in Hot Climates (London: Routledge)," (2002)

[11] F. Nicol,"Adaptive Thermal Comfort Standards in the hot - Humid Tropics Energy Build 36 628-37," (2018)

[12] S. Carr, "Public Space," Cambridge: Cambridge University Press, (1992)

[13] Peraturan Menteri Pekerjaan Umum Nomor 3 Tahun 2014 tentang Pedoman Perencanaan.

[14] N. T. Agency, "Pedestrian Planning and Design Guide," New Zealand : Land, (2009)

[15] B. Murtomo, "Arsitektur Kolonial Kota Lama Semarang," Jurnal Ilmiah Perancangan, (2008)

[16] A. N. Suri, "Arahan Konsep Perancangan Jalur Pedestrian yang Inklusif di Kawasan Kota Lama Semarang," UNDIP, Semarang, (2019)

[17] A. B. Purnomo, "Pengaruh Bayangan Bangunan dan Vegetasi pada Suhu Udara di Kampus A, Universitas Trisakti," DIMENSI TEKNIK ARSITEKTUR, vol. 31, no. 2, pp. 152-157, (2003)

[18] E. Y. Tisnaningtyas, "Aspek Kenyamanan Pejalan Kaki terhadap Iklim Tropis dan Aksesibilitas Pejalan Kaki di Lapangan Kota sebagai Kawasan Pedestrian," Jurnal Unpand, vol. 1, no. 2, (2015)

[19] A. Sutarto, " Alternatif Konsep Perancangan Fasilitas Koridor Hijau Bagi Pejalan Kaki Di Kampus Konservasi Unnes" Jurnal Unnes, 10, 2, (2012) 